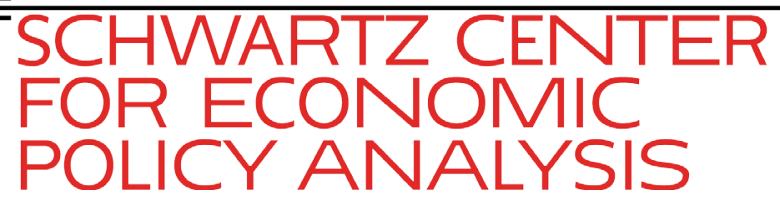

\title{
A Vertical Social \\ Accounting Matrix of the U.S. Economy
}

\section{Nelson H. Barbosa-Filho}

\author{
Schwartz Center for Economic Policy Analysis (SCEPA) \\ Department of Economics \\ The New School for Social Research \\ 6 East 16th Street, New York, NY 10003 \\ economicpolicyresearch.org
}

Suggested Citation: Barbosa-Filho, N. (2017) "A Vertical Social Accounting Matrix of the U.S. Economy." Schwartz Center for Economic Policy Analysis and Department of Economics, The New School for Social Research, Working

Paper Series 2017-1. 
1st version: February 6, 2017

\section{A Vertical Social Accounting Matrix of the US economy}

Nelson H. Barbosa-Filho*

Abstract: this paper presents an adaptation of the square social accounting matrix used in economic planning and programming to the rectangular or vertical transaction matrix used in post-Keynesian monetary economics. The objective is to obtain a simple and intuitive framework way to organize macroeconomic data in terms of the main institutional sectors of the economy, showing how production, distribution, demand and financing are inter-related. The papers presents the SAM of the US economy as an example and use it to analyze the trends in net lending and household net income since 1960.

Key words: social accounting matrix, US economy and post-Keynesian

JEL code: E16, N12 and A20

\footnotetext{
* Professor at the Getúlio Vargas Foundation (FGV) and the Federal University of Rio de Janeiro (UFRJ). The author would like to thank Lance Taylor and Rishabh Kumar for their comments and suggestions in a previous version of the matrix presented in this paper. The usual disclaimer applies. E-mail: nelson.barbosa@fgv.br.
} 


\section{A Vertical Social Accounting Matrix of the US Economy}

One agent's expenditure is always another agent's revenue. Someone's asset is always someone else's liability. These basic principles of accounting give us a roadmap to show how effective demand determines income, how income is distributed, and how these two issues change the debt-income ratios of different agents, which in their turn influence effective demand itself in subsequent periods.

Post-Keynesian monetary economics usually emphasizes the principle of effective demand and the consistency between the dynamics of stock and flow variables (Godley and Lavoie 2006), modeling the evolution of financial imbalances and leverage indexes (Minsky 1992). Despite the intuitive appeal of such view, its translation into applied models have been difficult due to the lack of easy data organized in terms of the stocks and flows of heterogeneous economic agents.

To develop the post-Keynesian research agenda, this paper presents a simplified Social Accounting Matrix (SAM) that summarizes the main flow variables of an open economy. The objective is to develop a simple methodology for teaching and research. To illustrate its application, we will present a simplified matrix of the US economy that links production, distribution, demand and net lending of four institutional sectors.

In terms of the post-Keynesian literature on the topic, the matrix presented in this paper is an adaptation of the usual "square" SAM used in Structuralist Computable General Equilibrium models (Taylor 1990) to the "rectangular" or "vertical" postKeynesian structure proposed by Godley and Lavoie (2006). The analysis translates the square SAM proposed by Taylor (2004) into a vertical SAM to facilitate the visual interpretation of the numbers.

The matrix presented in this paper is also an alternative way to organize the BEA's Integrated Macroeconomic Accounts (IMA) in one simple framework. ${ }^{1}$ The data come from the National Income and Product Accounts (NIPA) published by the US Bureau of Economic Analysis (BEA), and the Flow-of-Funds (FoF) or Financial Accounts of the US (FAUS) published by the Federal Reserve (Fed).

The analysis is in just three sections. Section one presents the US data for 2015 in a vertical SAM. Section two uses the vertical SAM to analyze the net lending of the main institution sectors of the US economy and the changes in the sources of household income that may explain the increase in income inequality since 1980. Section three concludes the analysis.

\footnotetext{
${ }^{1}$ The IMA is an attempt to match US NIPA and FoF data (Bond et all 2007 and Yamashita 2013). As we will see later, there are still large discrepancies between the sectoral net-lending numbers estimated from these two sources.
} 


\section{1 - The Vertical SAM of the US economy}

The US NIPA are currently organized in four main institutional sectors: households (HOU), business (BUS), government (GOV) and the rest of the world (ROW). The household sector includes households and non-profit institutions serving households. Some households' series can be divided between these two subgroups, but to simplify the analysis we will follow the BEA and treat them together as one institutional sector. ${ }^{2}$ The business sector includes both financial and non-financial firms, as well as corporate and non-corporate businesses. As it happens to households, some of the business's series can be disaggregated, but we will not do this here to keep things simple. ${ }^{3}$ The government sector includes the federal, state and local administrations. Government enterprises are part of the business sector and the rest of the world represents all non-resident agents that interact with US residents.

The starting point of the SAM is the definition of the value-added or Gross Domestic Product (GDP) of the economy. However, to represent the four institutional sectors it is useful to rewrite it in terms of aggregate supply (GDP plus imports) and aggregate demand (domestic absorption plus exports). Formally, in nominal terms we have

$P_{Y} Y+e P_{M}^{*} M=P_{C} C+P_{I} I+P_{X} X$

where $P_{j}$ represent the price index of real variable j, with j equal to GDP $(Y)$, imports $(M)$, consumption $(C)$, investment $(I)$ and exports $(X)$. The nominal exchange rate " $e$ " represents the domestic price of foreign currency and $P_{M}^{*}$ is the foreign price of imports.

From the demand data of the US economy, we can divide consumption in two sectors (households and government) and investment in three sectors (households, business and government). Formally:

$P_{Y} Y+e P_{M}^{*} M=P_{C}\left(C_{H O U}+C_{G O V}\right)+P_{I}\left(I_{H O U}+I_{B U S}+I_{G O V}\right)+P_{X} X$,

where $C_{i}$ and $I_{i}$ represent the real consumption and investment of sector $\mathrm{i}$.

Since by definition exports represent the final demand of the rest of the world for US products, the right-hand side of (2) already gives us the decomposition of aggregate demand by institutional sector. To obtain each sector's financial balance or net lending we have to divide the left-hand side of (2) in the "final income" available for each sector, that is, the net income after interest, dividends, taxes, benefits and any other

\footnotetext{
${ }^{2}$ The households sector can also be divided by income cohort, say: poor, middle and rich, using household surveys (Taylor et all 2014) or tax data (Piketty et all 2016) as a guide .

${ }^{3}$ In view of recent macroeconomic developments, the most useful division is between financial and nonfinancial firms, which has been recently expanded in the BEA's IMA (Kornfeld et all 2016).
} 
factor and transfers payments between our four institutional agents. This reallocation of income is one of the main parts of the SAM and it is crucial to determine each sector's financial balance and analyze its final demand.

Focusing on the supply, the initial income of each domestic institutional sector is the value it adds to intermediary inputs. The initial income of the rest of the world is simply the US imports and, to measure GDP in market prices, we also have to add net indirect taxes as an independent component of the nominal aggregate supply that belongs to the government. Formally:

$P_{Y} Y+e P_{M}^{*} M=P_{H O U} Y_{H O U}+P_{B U S} Y_{B U S}+P_{G O V} Y_{G O V}+e P_{M}^{*} M+T$,

where $Y_{i}$ is the real value added by sector $\mathrm{i}$ and $T$ represents indirect taxes minus subsidies in nominal terms. Note that if we subtract imports from both sides of (3) we have the usual identity between GDP at market prices and GDP at production prices plus net indirect taxes. As we proceed, it will become clear why it is better to start with an equation for total supply rather than for GDP to explain all the determinants of net lending.

Moving to the US data, table 1 presents the value of (3) for 2015. The numbers indicate a total supply of $\$ 20,823$ billion, with $\$ 18,037$ billion from domestic sources (GDP) and $\$ 2,786$ billion from the rest of the world (imports). The BEA data also allows us to decompose domestic GDP in the main components of the value added by each institutional sector.

\section{TABLE 1 HERE}

The compensation of domestic employees was $\$ 9,704$ billion in 2015 , paid mostly by the business and government sectors. Approximately $81 \%$ of this compensation consisted of wage and salaries, which are readily available for spending by households after taxes and transfers. The remaining $19 \%$ were employers' contributions to private pensions and insurance funds and to government social security, which represents a forced or compulsory saving by households.

Since all domestic sectors invest, all of them have an imputed income from capital consumption, which totaled $\$ 2,831$ billion in 2015 . By definition, only the business sector had a net operating surplus from production, which was \$ 4,575 billion in 2015. As we will see below, most of this surplus was reallocated to households as capital income. The gross operating surplus also includes a statistical discrepancy in the US case, which corresponds to the difference between income registered from the 
production and income sides of the NIPA. ${ }^{4}$ To complete the picture, all net indirect taxes goes to the government and all imports to the rest of the world.

In economic terms, table 1 indicates that the business sector received $63.9 \%$ of total supply at market prices in 2015 , with the government coming in second with $16.3 \%$, and the rest of the world in third with $13.4 \% .{ }^{5}$ Households received only $6.4 \%$ of total supply in 2015, but this was not their final income. In fact, all labor compensation goes to families and part of the business net operating surplus is redistributed across sectors as proprietors' income, rents, dividends, and other asset categories. To see how this happens, table 2 shows the numbers for 2015.

\section{TABLE 2 HERE}

In words, all labor compensation paid by the business (\$7,155 billion) and government ( $\$ 1,697$ billion) sectors goes to the household sector. In addition to this, there are also labor receipts and payments between households' and the rest of the world due to the wages and salaries of non-resident workers. This kind of flow represented a net US payment of $\$ 11$ billion to the rest of the world in 2015 .

Moving to capital income, by definition the business sector pays all proprietors' and rental income of the household sector, which amounted to $\$ 1,377$ billion and $\$ 660$ billion in 2015, respectively. The next category is dividends, which is usually a net payment of the business sector to the other domestic sectors. Since the rest of the world also pays and receives dividends, its net income from this source can be positive, negative or even zero. In 2015 the rest of the world paid $\$ 130$ billion to the US in net dividends, which together with the net payments of $\$ 841$ billion by the business sector raised the households' income in $\$ 951$ billion, and the government income in $\$$ 20 billion. ${ }^{6}$

Table 2 also shows that, in addition to dividends, households received a net interest income of $\$ 1,039$ billion in 2015, while the rest of the world received $\$ 169$ billion. Since the values must cancel out, the net interest payments came from the business and government sectors, with $\$ 672$ and $\$ 536$ billion, respectively. The total amount of interest payments was $\$ 3,483$ billion in 2015 (19\% of GDP) and the BEA's data breaks these flows by institutional sector, as also shown in table $2 .^{7}$

\footnotetext{
${ }^{4}$ The BEA's statistical discrepancy equals GDP minus Gross Domestic Income (GDI). A negative statistical discrepancy means, therefore, that GDP was smaller than GDI in the period under analysis.

${ }^{5}$ We will see how this and other issues evolved in time in the next section.

${ }^{6}$ The current structure of the BEA's NIPA does not present bilateral dividends and interest flows. Because of this, table 2 presents only the total receipts and payments by institutional sector. ${ }^{7}$ In 2015, 29\% of the total interest payments (\$1,010 billion) were imputed flows due to financial services.
} 
The final three types of capital income are the intra-firm flows between the US and the rest of the world and the government asset receipts and payments. In 2015, the rest of the world made a net payment of $\$ 255$ billion to the business sector as reinvested earnings, while the business sector paid $\$ 21$ billion to the government through rents and royalties. The government also had a negative capital income from government enterprises, which registered a current deficit of \$19 billion in 2015 .

Note that one sector's payment is another sector's receipt in all factor income flows reallocated in table 2 . The sum of the reallocated labor and capital income flows is therefore zero in last column of table 2 . The total value of the sectors' initial income remains the same in the last line of the same table, but its composition change substantially. For example, the income of the household sector increased from \$1,324 billion from production to $\$ 14,191$ after the reallocation of labor and capital income. The offsetting reduction was concentrated mostly in the business sector, but the government and the rest of the world were also net payers of factor income in 2015.

Overall, when we include the reallocation of factor income in the analysis, the household sector received $68.2 \%$ of the nominal aggregate supply or demand in 2015. The shares of the business and rest-of-the-world sectors were $13.7 \%$ and $12.4 \%$ respectively, while the government ended up with $5.7 \%$ of aggregate supply because of its high labor-compensation and net-interest payments.

The third step to build our vertical SAM is to include taxes and transfers in the analysis. To do this, we have to subtract direct tax payments and social contributions from the private sectors and add them to the government. In the reverse direction, we have to add social benefits to the private sectors' income and subtract them from the government. Table 3 shows the numbers for 2015 .

\section{TABLE 3 HERE}

Focus on the government column of table 3 . Total current taxes were $\$ 2,476$ billion in 2015 and most of it came from the household sector. The same applies to the contributions for social insurance, which totaled $\$ 1,209$ billion in 2015. In the reverse direction, the government paid $\$ 2,648$ billion in social benefits during that year, with almost all of it going to the household sector. To complete the picture, all other current transfers represented an additional net income of $\$ 169$ billion for the government and $\$ 168$ billion for the rest of the world in 2015 . The net payers were therefore the household and business sectors, with $\$ 137$ billion and $\$ 200$ billion, respectively. ${ }^{8}$

\footnotetext{
${ }^{8}$ With four institutional sectors, we should have twelve bilateral flows of other transfers in table 3 . We present only nine bilateral flows because the BEA data contains only the net values of some transfers between our four institutional sectors.
} 
Table 3 also shows the final income of each sector, that is, the net income available for final expenditures on consumption, investment and exports. By construction, the total final income is equal to the aggregate supply or demand, and its composition gives us one of the necessary variables to calculate the net lending of each institutional sector. Before we move to that, note that after the reallocation of factor income, taxes and transfers, the household final income represented 65\% of aggregate supply in 2015. The rest of the world comes in second with $13.2 \%$, and the government in third with $11.5 \%$. The final income of the business sectors consists of undistributed net profits from domestic and foreign sources and it represented $10.3 \%$ of aggregate supply in 2015.

Now, to obtain the net lending of each institutional sector we have to subtract final expenditures from final income and add capital transactions to the analysis. ${ }^{9}$ Table 4 shows the numbers for 2015 and it can be summarized as follows:

(i) the household sector had a final income of $\$ 13,539$ billion and a final demand of $\$ 12,972$ (\$12,284 billion in consumption and $\$ 688$ billion in investment), with a current-account surplus of $\$ 567$;

(ii) the business sector had a final income of $\$ 2,146$ billion, spent $\$ 2,369$ billion in investment, and had a current-account deficit of $\$ 223$ billion;

(iii) the government had a final income $\$ 2,396$ billion, spent $\$ 2,605$ billion in consumption and $\$ 613$ billion in investment, and also had a currentaccount deficit, of $\$ 882$ billion; and

(iv) the rest of the world had a final income of $\$ 2,742$ billion from its transactions with the US, spent $\$ 2,264$ billion in US products, and registered a current-account surplus of $\$ 477$ billion.

\section{TABLE 4 HERE}

Still on table 4, net lending is equal to the current-account surplus plus capital transactions. In 2015, the household and business sectors made a net payment of $\$ 13$ and $\$ 27$ billion in capital transactions, respectively, while the government had a net receipt of $\$ 40$ billion and the rest of the world of $\$ 1$ billion. In relative terms, the surpluses of households and the rest of the world represented $2.7 \%$ and $2.3 \%$ of aggregate demand in 2015 , respectively. The government deficit was $3.8 \%$ of aggregate demand, while the business sector had a deficit of $1.2 \%$ of aggregate demand.

\footnotetext{
${ }^{9}$ Capital transactions consists of transfers of capital and transactions involving non-produced nonfinancial assets.
} 
Before we proceed to the US time series, note that we can also rearrange table 4 in terms of saving and investment, which are the usual concepts of economists to define net lending. To do this we just have to separate capital from non-capital final expenditures and define final saving as the difference between final income and noncapital final expenditures. Table 5 does this and it also shows the net savings and investment of each institutional sector in 2015.

\section{TABLE 5 HERE}

Now, if we stack tables 1 through 4 up we have a vertical SAM, that is, a map to move from the initial income from production (aggregate supply) to the net lending of each institutional sector. In this process, we allocate all labor and capital income and distribute all current transfers and final demand (aggregate demand) by institutional sector. Table 6 shows the complete vertical SAM, with the consolidated values of some accounts to simplify the exposition. The columns show the determination of the net lending of each institutional sector, while the rows show the distribution of each macro variable or account across our four sectors.

\section{TABLE 6 HERE}

Finally, since net lending is equal to the net acquisition of financial assets, we can add more lines to table 6 to register how this is distributed in, say, money, bonds, equities and other financial assets. The BEA's does that in its IMA, but there are large discrepancies between the net lending numbers estimated from the NIPA and the FoF. To show this, table 7 presents the decomposition of each sector net lending by main financial instrument. ${ }^{10}$ The data comes from the Fed's FoF and to make it consistent with the NIPA, table 7 also includes the discrepancies between the BEA and Fed numbers.

\section{TABLE 7 HERE}

To facilitate the exposition, table 7 details only the net changes in the assets for which the FoF data add up to zero, since an increase in the asset by one sector must be matched by a reduction in the same asset of the other sectors. To assure macroeconomic consistency, all asset groups for which this accounting identity does not hold are grouped under the label "other assets", and its total value is by definition equal to symmetric of the discrepancy between the NIPA and FoF numbers. ${ }^{11}$

To explain table 7 in more intuitive terms, consider the household sector. According to the NIPA, the households' net lending was $\$ 554$ billion in 2015, whereas according to

\footnotetext{
${ }^{10}$ For another way to match the NIPA with the FoF data, see Taylor (2004, chapter 1 ).

${ }^{11}$ According to the Fed's FoF, in 2015 most of this "instrument" discrepancy came from foreign deposits, fed-funds and repo operations, taxes payable and "miscellaneous assets".
} 
the FoF data it was $\$ 895$ billion. The BEA-FoF discrepancy is therefore minus $\$ 341$ billion, as shown in the last line of table 7. Focusing on the Fed's numbers, the US households increased their holdings of money (currency and checkable deposits) in \$ 149 billion, and of saving and time deposits in $\$ 502$ billion. Households also reduced their shares in money-market funds in $\$ 45$ billion, acquired more $\$ 157$ billion in debt securities and took $\$ 450$ billion in net new loans. To complete the picture, households also increased their holdings of equities ( $\$ 36$ billion), mutual-fund shares ( $\$ 58$ billion), life-insurance reserves ( $\$ 36$ billion), pension entitlements ( $\$ 436$ billion) and other assets ( $\$ 17$ billion).

By analogy, the above reasoning can be applied to the other institutional sectors to map who lends to whom, through which instrument, to analyze financial intermediation. In the same vein, we can deduct the flow changes in financial assets shown in table 7 from its total changes from a financial wealth matrix to obtain the capital gains and losses by financial instrument (Godley and Lavoie 2006). Recent studies indicate that capital gains and losses tend to explain most of the changes in financial wealth in recent decades (Roth 2016), but this issue is beyond the scope of this paper.

\section{2-Net lending and changes in the sources of US household final income}

The data presented in the previous section can be used to analyze many topics. This section gives a brief example of this kind of analysis using net lending and the sources of US household income.

The US NIPA time series start in 1929, with annual frequency, and in 1947, with quarterly frequency. The division of the US economy in four sectors can only be done from 1960 onwards, since the BEA separates households' from firms' investment starting in that year. Earlier estimates can be obtained by adopting a proxy for the households' investment, ${ }^{12}$ but we will focus mostly in the post-1960 period to use only official BEA data in this paper. Unless stated otherwise, all series are represented in terms of GDP in this section.

Starting with the longest time series, figure 1 shows the data for three institutional sectors since 1929: private, government and business. The numbers indicate that most of the fluctuations in the government deficit were absorbed by the private sector, not by the foreign surplus as assumed by the twin-deficits hypothesis. ${ }^{13}$ The net lending by the rest of the world did increase since 1980, but this did not eliminate the high

\footnotetext{
${ }^{12}$ For example, allocating all residential investment to households. The post-1960 data show that household and residential investment are close, but do not necessarily coincide.

${ }^{13}$ This confirms the analysis of Barbosa-Filho et all (2008).
} 
correlation between the private and government financial imbalances. The highest government net borrowing occurred during World War II (25.4\% of GDP in 1944), followed by the Great Recession of recent years (12.8\% of GDP in 2009).

\section{FIGURE 2 HERE}

Figure 2 also shows that the private sector became a temporary net borrower of funds only in recent decades, that is, during the private debt cycles of the late 1990s (the dot-com bubble) and the mid-2000s (the housing bubble). Excluding years of war and speculative bubbles, the government net borrowing fluctuated around 5\% of GDP and the private sector absorbed most of it until 1980. Since then foreign saving has become an important source of funds for US investment and currently it represents $2.6 \%$ of the US GDP. ${ }^{14}$

\section{FIGURE 1 HERE}

Moving to our four institutional sectors, figure 2 shows the net lending since 1960 . The series for the government and the rest of the world are the same as in figure 1 . The breakdown of the private sector between households and business indicates that firms were the main private borrowers in the late 1990s (the dot-com bubble), while families assumed this role in the mid-2000s (the housing bubble). Government net borrowing fluctuated around 5\% of GDP since the 1970s, but with an increasing volatility. The net borrowing of the business sector fluctuated around zero, but also with an increasing volatility. Excluding the recent and temporary demand expansion caused by the housing bubble, the household sector has been a net lender in the US economy during most of the period under analysis, but with a clear reduction in its surplus after 1980. To compensate this, the rest of the world became an important institutional net lender of funds since 1980 .

\section{FIGURE 2 HERE}

The natural question from figures 1 and 2 is what caused the changes in net lending or borrowing? To answer this using the concepts developed in the previous section, figure 3 presents the final income and demand of the four institutional sectors of the US economy. The numbers clearly show a gradual increase in the household final income and a gradual reduction in the government final income since 1970. The final demand of both sectors moved in the same direction of their final income, with a temporary sharp fall in the household net lending before the 2008 financial crisis, and a temporary sharp increase in the government net borrowing immediately after it.

\footnotetext{
${ }^{14}$ This is approximately $0.7 \%$ of the rest of the world's GDP assuming that the US currently represents $25 \%$ of nominal world income, as shown by the recent IMF data.
} 
Comparing the early 1960s with recent years, the final income and demand of households increased in approximately $6 \%$ of GDP. The main drivers of this have been ageing - which reduces contributions to social insurance and raise its benefits - and the increase in household capital income - mostly through net interest and dividend income. On the other side, the government final income dropped in approximately $7 \%$ of GDP since the early 1960 s, while its final demand fell in $4 \%$ of GDP.

The final income and demand of the business sector fluctuated around $13 \%$ of GDP during most of the period under analysis, with more volatile surpluses and deficits since 1990. In fact, the business sector was a net lender of funds up to 1975 . Since then it started to alternate surpluses and deficits, with its final income and demand moving in almost opposite directions since 1990. The fluctuation in business net lending also tended to lead fluctuations in the level of economic activity during the period of analysis, following the dynamics of a profit-led profit-squeeze economy (Barbosa-Filho and Taylor 2006).

The final income and demand of the rest of the world show a positive trend between 1970 and 2010, with an increasing current-account deficit for the US up until recently. More specifically, there were two clear cycles of increasing and decreasing currentaccount deficits for the US since the 1960s: one between 1982 and 1991 and the other between 1991 and 2009. The first and short cycle is associated with the appreciation and depreciation of the US dollar that marked the 1980s. The second and long cycle is associated with financial liberalization across the world after the fall of the Berlin Wall and it reached its peak in 2006. There were periods of appreciation and depreciation of the US dollar during the second cycle, which seems to have ended with the financial crisis of 2008. Since then the net-lending of the rest of the world has stabilized around $2.6 \%$ of US GDP, but the recent presidential election in the US indicate that this will probably change in the near future.

The increase in the household final income has happened together with a reduction in the labor share of income in the US economy. To put this in historical perspective, figure 4 shows the compensation of employees in terms of the net domestic product at producer prices. This variable corresponds to what mainstream economics associate with the labor-elasticity of the aggregate production function, but in reality it depends on many more things than technology (McCombie and Felipe 2013). For the purpose of this paper, it should be noted that there was a clear upward trend in the labor share in the 1950 s and 1960s - the period of financial repression - and a downward trend since 1980 - when the current period of wage repression started. ${ }^{15}$

\footnotetext{
${ }^{15}$ By wage repression I mean structural changes that reduces workers' bargaining power in the labor market. In the US this has been driven mostly by four factors since the 1980s: technological change or the "information revolution", trade opening or "globalization", the relative increase in the demand for services and the pro-capital changes in labor and tax legislation. For a model of employment and the labor share of income applied to the US, see Barbosa-Filho (2015).
} 
In fact, if we ignore the volatile 1930s and 1940s, the labor share rose in approximately 7 percentage points (pp) of the US net product between the early 1950s and the early 1970s, and fell $3 \mathrm{pp}$ since then. This movement shows that some of the pro-labor structural changes that happened in the US during the 1950s and 1960s may be permanent or, at least, persistent.

\section{FIGURE 4 HERE}

Moving back to the institutional distribution of income, the pro-capital change in the composition of income also appears in our four-sector model. To represent it, figure 5 shows the share of the net labor and capital income of the household sector since 1960. ${ }^{16}$ The net labor income is just the compensation of domestic employees plus the net wages and salaries received from abroad, whereas the capital income is the sum of all proprietors', rent, net-interest and dividend income that we mentioned in table 2 of the previous section. To facilitate the analysis, labor income is represented in the left scale, and capital income in the right scale of figure 5 . The numbers clearly show a reduction in employee's compensation - from $57 \%$ to $53 \%$ of GDP between the late 1960 s and the early 2010s. The numbers also show a symmetric increase in household capital income - from $18 \%$ to $22 \%$ of GDP in the same period. Since most of capital income goes to the richest cohorts of the population, the pro-capital shift depicted in figure 5 is an alternative way to represent the worsening in the personal distribution of US income since the 1980s (Piketty 2014).

\section{FIGURE 5 HERE}

To explain the increase in the household capital income, figure 6 presents its main components since 1960. Four trends appear clearly in the data. First, there was a sharp and substantial increase in net interest income after the Volcker monetary shock of the early 1980s. In fact, presumably rich households received approximately $12 \%$ of the US GDP during the 1980s. Net interest payments fell since then and are now at $6 \%$ of GDP, which was their level at the end of the 1960s.

Second, proprietors' income diminished gradually from 9\% of GDP in the early 1960s to $5 \%$ of GDP in the mid-1980s, pulled by the relative reduction in farm income. ${ }^{17}$ After that, proprietors' income took up and reached $8 \%$ in the early 2000 s due to the rise in non-farm self-employment that accompanied wage repression.

Third, household dividend income reached its lowest relative level in 1975, 2\% of GDP, and started to grow gradually in the subsequent twenty years. This trend accelerated

\footnotetext{
${ }^{16}$ The third component of household final income consists of net taxes, contributions, benefits and other current transfers received, described in table 3 of the previous section.

${ }^{17}$ Other BEA series indicate that half of this fall was due to the reduction in farm income in terms of GDP.
} 
in the early 2000s, when household dividend income peaked at almost $6 \%$ of GDP. The financial crisis diminished dividends temporarily after 2008, but this source of capital income rose back to its pre-crisis level in recent years. If the current trend continues, dividend income will soon become the second most important source of capital income for households, below proprietors' income and above net interest.

Finally, household net rental income seems to track inflation and the stock of residential capital. More specifically, because of the acceleration of inflation, this source of fixed income fell from 3\% of GDP, in the late 1960s, to less than $1 \%$ of GDP, in the early 1980s. Personal rental income started to recover only in the 1990s and, due to the recent low inflation and rise in residential capital, it reached its highest historical level in 2015, 3.7\% of GDP.

\section{FIGURE 6 HERE}

To complete our analysis of the sources of household final income, figure 7 shows the net-tax, social-contribution and social-benefit income by institutional sector since 1960. Naturally, the government is the net receiver of this kind of flow, with business and households as the main net payers. The net current taxes paid by business fell from $4 \%$ of GDP in the 1960 s to $3 \%$ of GDP in recent years. This reduction is small compared to what happened with the net payments by households: after peaking in the early 2000s - at approximately $9 \%$ of GDP - household net taxes and contributions fell to just 3\% of GDP in recent years. In fact, immediately after the 2008 crisis, households temporarily received more in social benefits than they paid in taxes and social contributions. The long-run main drivers of this change have been the ageing of the US population and the regressive changes in direct taxation since the 1980s. As a result, the government net income from taxes and social contributions is currently half of what it used to be in the late 1960s, when measured in terms of GDP.

\section{FIGURE 7 HERE}

\section{Conclusion}

The methodology of SAMs have been laid out a long time ago and used extensively for economic planning (Pyatt 1985), especially of development issues and in association with Leontief input-output matrices. In addition to such use, SAM methodology can also be applied to analyze income distribution and financial flows (Taylor 2004) since it constitutes the basis or "macrofoundation" of post-Keynesian monetary economics (Godley and Lavoie 2006).

Most SAMs are presented in a square form due to its Leontief inspiration, but its structure and interpretation becomes much simpler in a rectangular or vertical monetary form as presented in this paper. In fact, the vertical SAM gives us a summary 
of production, distribution, demand and financing in an open economy, which can be used to analyze many macroeconomic issues in a consistent or general-equilibrium framework. The vertical form can also be easily complemented by flow-of-funds data on the allocation of net lending by financial instrument.

To give an example of the application of SAMs, this paper presented the US data in terms of four institutional sectors and analyzed the changes in the main sources of household income since 1960 . The data show an increase in the volatility of financial imbalances since 1990s and a structural pro-capital change in household income since the 1980s. These two results are consistent with the higher macroeconomic volatility and income inequality associated with financial liberalization and wage repression that marked the US economy in recent decades.

\section{References:}

Barbosa-Filho, N.H. (2015). "Elasticity of substitution and social conflict: a structuralist note on Piketty's Capital in the Twenty-first Century", Cambridge Journal of Economics 40(4), pp.1167-1183.

Barbosa-Filho, N.H. and Taylor, L (2006). "Distributive and Demand Cycles in the US Economy - a Structuralist Goodwin Model", Metroeconomica 57(3), pp.389411.

Barbosa-Filho, N.H., Von-Arnim, C.R., Taylor,L. and Zamparelli, L. (2008). "Cycles and Trends in US net borrowing flows", Journal of Post Keynesian Economics 30(4), pp. 623-648.

Bond, C.A., Martin, T., Mclntosh, S.H. and Mead, C.I. (2007). "Integrated Macroeconomic Accounts for the United States", BEA Briefing 2007, pp. 14-31.

Godley,W. and Lavoie, M. (2006). Monetary Economics: An Integrated Approach to Credit, Money, Income, Production and Wealth, New York: Palgrave MacMillan.

Kornfeld, R.J., Lynn, L. and Yamashita, T. (2016). "Expanding the Integrated Macroeconomic Accounts' Financial Sector", BEA Briefing 2016, pp. 1-15

McCombie, J.S.L and Felipe, J. (2013). The Aggregate Production Function and the Measurement of Technical Change: Not Even Wrong, London: Edward Elgar.

Minsky, H. (1992). "The Financial Instability Hypothesis", Working Paper 74, The Jerome Levy Economics Institute.

Piketty, T. (2014). Capital in the $21^{\text {st }}$ Century, Cambridge: Harvard University Press.

Piketty, T., Saez, G. and Zucman, G. (2016). “Distributional National Accounts: Methods and Estimates for the United States", NBER Working Paper 22945.

Pyatt, G. (1985), Social Accounting Matrices, a Basis for Planning, Washington DC: World Bank. 
Roth, S. (2016), "Why Economists Don't Know How to Think about Wealth (or Profits)" Text published in Evonomics (http://evonomics.com/economists-dont-knowthink-wealth-profits/). Access on January 30, 2017.

Taylor, L. (1990). "Structuralist CGE Models" in: L. Taylor (ed), Socially Relevant Policy Analysis: Structuturalist Computable General Equilibrium Models for the Developing World, Cambridge: The MIT Press.

Taylor, L. (2004), Reconstructing Macroeconomics, Cambridge: Harvard University Press, 2004.

Taylor, L., Rezai, A., Kumar, R., Barbosa-Filho, N.H, and Carvalho, L. (2014). “Wage Increases, Transfers, and the Socially Determined Income Distribution in the US", INET Working Paper 11.

Yamashita, T. (2013). "A Guide to the Integrated Macroeconomic Accounts", BEA Briefing 2013, pp. 12-27. 
Table 1: US 2015 initial income flows by institutional sectors, in billions of USD dollars, receipts (+) or payments (-).

\begin{tabular}{|c|r|r|r|r|r|}
\hline & \multicolumn{1}{|c|}{ HOU } & \multicolumn{1}{c|}{ BUS } & \multicolumn{1}{c|}{ GOV } & \multicolumn{1}{c|}{ ROW } & \multicolumn{1}{c|}{ Total } \\
\hline Initial income (GDP+imports) & $\mathbf{1 , 3 2 4}$ & $\mathbf{1 3 , 3 1 3}$ & $\mathbf{3 , 4 0 0}$ & $\mathbf{2 , 7 8 6}$ & $\mathbf{2 0 , 8 2 3}$ \\
\hline Compensation of employees & 852 & $\mathbf{7 , 1 5 5}$ & 1,697 & & 9,704 \\
\hline Wages and salaries & $\mathbf{7 0 5}$ & 5,997 & 1,164 & & $\mathbf{7 , 8 6 6}$ \\
\hline Supplements & 147 & 1,159 & 533 & & 1,838 \\
\hline Gross operating surplus & 472 & 6,157 & 523 & & 7,152 \\
\hline Net operating surplus & & 4,575 & & & 4,575 \\
\hline Capital consumption & 472 & 1,837 & 523 & & 2,831 \\
\hline Statistical discrepancy & & -254 & & & -254 \\
\hline Net indirect taxes & & & 1,181 & & 1,181 \\
\hline Imports & & & & 2,786 & 2,786 \\
\hline Memo: initial income in \% of row total & 6.4 & 63.9 & 16.3 & 13.4 & 100.0 \\
\hline
\end{tabular}

Source: BEA and author's definitions. HOU represents households and non-profit institutions, BUS business, GOV government and ROW the rest of the world.

Table 2: US 2015 reallocation of labor and capital income by institutional sector in billions of US dollars, receipts (+) or payments (-)

\begin{tabular}{|c|c|c|c|c|c|}
\hline & $\mathrm{HOU}$ & BUS & GOV & ROW & Total \\
\hline 1) Initial income (from production) & 1,324 & 13,313 & 3,400 & 2,786 & 20,823 \\
\hline 2) Reallocation of labor income & 8,841 & $-7,155$ & $-1,697$ & 11 & $\mathbf{0}$ \\
\hline Domestic flows & 8,852 & $-7,155$ & $-1,697$ & & 0 \\
\hline International flows & -11 & & & 11 & 0 \\
\hline Wages and salaries received & 7 & & & -7 & 0 \\
\hline Wages and salaries paid & -18 & & & 18 & 0 \\
\hline 3) Reallocation of capital income & 4,026 & $-3,296$ & -513 & -217 & 0 \\
\hline Proprietors' income & 1,377 & $-1,377$ & & & 0 \\
\hline Rental income & 660 & -660 & & & 0 \\
\hline Net dividend income & 951 & -841 & 20 & -130 & 0 \\
\hline Receipts & 951 & 578 & 20 & 183 & 1,733 \\
\hline Payments & 0 & $-1,419$ & 0 & -314 & $-1,733$ \\
\hline Net interest income & 1,039 & -672 & -536 & 169 & 0 \\
\hline Receipts & 1,303 & 1,769 & 88 & 324 & 3,483 \\
\hline Payments & -264 & $-2,441$ & -623 & -154 & $-3,483$ \\
\hline Net reinvested earnings received & & 255 & & -255 & 0 \\
\hline From ROW & & 338 & & -338 & 0 \\
\hline To ROW & & -83 & & 83 & 0 \\
\hline Government rents and royalties & & -21 & 21 & & 0 \\
\hline Current surplus of gov enterprises & & 19 & -19 & & 0 \\
\hline 4) Income after factor reallocation $(1+2+3)$ & 14,191 & 2,861 & 1,190 & 2,581 & 20,823 \\
\hline Memo: \% of row total & 68.2 & 13.7 & 5.7 & 12.4 & 100.0 \\
\hline
\end{tabular}

Source: BEA and author's definitions. HOU represents households and non-profit institutions, BUS business, GOV government and ROW the rest of the world. 
Table 3: US 2015 taxes, social contributions, social benefits, and other current transfers by institutional sector in billions of US dollars, receipts (+) or payments (-)

\begin{tabular}{|c|c|c|c|c|c|}
\hline & $\mathrm{HOU}$ & BUS & GOV & ROW & Total \\
\hline 1) Income after factor reallocation & 14,191 & 2,861 & 1,190 & 2,581 & 0 \\
\hline 2) Taxes and transfers & -652 & -715 & 1,206 & 161 & 0 \\
\hline Current taxes & $-1,939$ & -515 & 2,476 & -22 & 0 \\
\hline Contibutions to Social Insurance & $-1,204$ & & 1,209 & -5 & 0 \\
\hline Social benefits & 2,627 & & $-2,648$ & 20 & 0 \\
\hline Other current tranfers & -137 & -200 & 169 & 168 & 0 \\
\hline ROW to HOU & 98 & & & -98 & 0 \\
\hline ROW to BUS & & 1 & & -1 & 0 \\
\hline ROW to GOV & & & 7 & -7 & 0 \\
\hline HOU to ROW & -184 & & & 184 & 0 \\
\hline BUS to ROW & & -39 & & 39 & 0 \\
\hline GOV to ROW & & & -52 & 52 & 0 \\
\hline HOU to GOV (net) & -103 & & 103 & & 0 \\
\hline BUS to HOU (net) & 51 & -51 & & & 0 \\
\hline BUS to GOV (net) & & -111 & 111 & & 0 \\
\hline 3) Final income $(1+2)$ & 13,539 & 2,146 & 2,396 & 2,742 & 20,823 \\
\hline Memo: $\%$ of row total & 65.0 & 10.3 & 11.5 & 13.2 & 100.0 \\
\hline
\end{tabular}

Source: BEA and author's definitions. HOU represents households and non-profit institutions, BUS business, GOV government and ROW the rest of the world.

Table 4: US 2015 final income, final demand and net lending by institutional sector, in billions of USD, receipts (+) or payments (-)

\begin{tabular}{|c|c|c|c|c|c|}
\hline & HOU & BUS & GOV & ROW & Total \\
\hline 1) Final income & 13,539 & 2,146 & 2,396 & 2,742 & 20,823 \\
\hline 2) Final demand & $-12,972$ & $-2,369$ & $-3,218$ & $-2,264$ & $-20,823$ \\
\hline Consumption & $-12,284$ & & $-2,605$ & & $-14,889$ \\
\hline Investment & -688 & $-2,369$ & -613 & & $-3,670$ \\
\hline Exports & & & & $-2,264$ & $-2,264$ \\
\hline 3) Current-account balance (1-2) & 567 & -223 & -822 & 477 & 0 \\
\hline 4) Capital transactions & -13 & -27 & 40 & 1 & 0 \\
\hline 5) Net lending (3+4) & 554 & -249 & -782 & 478 & 0 \\
\hline Memo: \% of total fnal income & 2.7 & -1.2 & -3.8 & 2.3 & 0.0 \\
\hline
\end{tabular}

Source: BEA and author's definitions. HOU represents households and non-profit institutions, BUS business, GOV government and ROW the rest of the world. 
Table 5: US 2015 saving, investment and net lending by institutional sector in billions of USD, receipts (+) or payments (-)

\begin{tabular}{|c|c|c|c|c|c|}
\hline & $\mathrm{HOU}$ & BUS & GOV & ROW & Total \\
\hline 1) Final income & 13,539 & 2,146 & 2,396 & 2,742 & 20,823 \\
\hline 2) Non-capital final demand & $-12,284$ & 0 & $-2,605$ & $-2,264$ & $-17,153$ \\
\hline Consumption & $-12,284$ & & $-2,605$ & & $-14,889$ \\
\hline Exports & & & & $-2,264$ & $-2,264$ \\
\hline 3) Gross saving $(1+2)$ & 1,255 & 2,146 & -209 & 477 & 3,670 \\
\hline Net saving & 784 & 309 & -731 & 477 & 839 \\
\hline Capital consumption & 472 & 1837 & 523 & & 2,831 \\
\hline 4) Investment & -688 & $-2,369$ & -613 & 0 & $-3,670$ \\
\hline Net investment & -216 & -532 & -91 & & -839 \\
\hline Capital consumption & -472 & -1837 & -523 & & $-2,831$ \\
\hline 5) Current-account balance (3-4) & 567 & -223 & -822 & 477 & 0 \\
\hline 6) Capital transactions & -13 & -27 & 40 & 1 & 0 \\
\hline 7) Net lending $(5+6)$ & 554 & -249 & -782 & 478 & 0 \\
\hline
\end{tabular}

Source: BEA and author's definitions. HOU represents households and non-profit institutions, BUS business, GOV government and ROW the rest of the world. 
Table 6: US 2015 Vertical Social Accounting Matrix, in billions of USD, receipts (+) or payments (-)

\begin{tabular}{|c|c|c|c|c|c|}
\hline & $\mathrm{HOU}$ & BUS & GOV & ROW & Total \\
\hline 1) Initial income (GDP+imports) & 1,324 & 13,313 & 3,400 & 2,786 & 20,823 \\
\hline Compensation of employees & 852 & 7,155 & 1,697 & & 9,704 \\
\hline Gross operating surplus & 472 & 6,157 & 523 & & 7,152 \\
\hline Net indirect taxes & & & 1,181 & & 1,181 \\
\hline Imports & & & & 2,786 & 2,786 \\
\hline 2) Reallocation of labor income & 8,841 & $-7,155$ & $-1,697$ & 11 & 0 \\
\hline Domestic flows & 8,852 & $-7,155$ & $-1,697$ & & 0 \\
\hline International flows & -11 & & & 11 & 0 \\
\hline 3) Reallocation of capital income & 4,026 & $-3,296$ & -513 & -217 & 0 \\
\hline Proprietors' income & 1,377 & $-1,377$ & & & 0 \\
\hline Rental income & 660 & -660 & & & 0 \\
\hline Net dividend income & 951 & -841 & 20 & -130 & 0 \\
\hline Net interest income & 1,039 & -672 & -536 & 169 & 0 \\
\hline Net reinvested earnings received & & 255 & & -255 & 0 \\
\hline Government rents and royalties & & -21 & 21 & & 0 \\
\hline Current surplus of gov enterprises & & 19 & -19 & & 0 \\
\hline 4) Taxes and transfers & -652 & -715 & 1,206 & 161 & 0 \\
\hline Current taxes & $-1,939$ & -515 & 2,476 & -22 & 0 \\
\hline Contibutions to Social Insurance & $-1,204$ & & 1,209 & -5 & 0 \\
\hline Social benefits & 2,627 & & $-2,648$ & 20 & 0 \\
\hline Other current tranfers & -137 & -200 & 169 & 168 & 0 \\
\hline 5) Final income $(1+2+3+4)$ & 13,539 & 2,146 & 2,396 & 2,742 & 20,823 \\
\hline 6) Final demand & $-12,972$ & $-2,369$ & $-3,218$ & $-2,264$ & $-20,823$ \\
\hline Consumption & $-12,284$ & & $-2,605$ & & $-14,889$ \\
\hline Investment & -688 & $-2,369$ & -613 & & $-3,670$ \\
\hline Exports & & & & $-2,264$ & $-2,264$ \\
\hline 7) Current-account balance $(5+6)$ & 567 & -223 & -822 & 477 & 0 \\
\hline 8) Capital transactions & -13 & -27 & 40 & 1 & 0 \\
\hline 9) Net lending $(7+8)$ & 554 & -249 & -782 & 478 & 0 \\
\hline
\end{tabular}

Source: BEA and author's definitions. HOU represents households and non-profit institutions, BUS business, GOV government and ROW the rest of the world. 
Table 7: US 2015 Flow of Funds in billions of USD, net lending (+) or net borrowing (-) by financial instrument.

\begin{tabular}{|c|c|c|c|c|c|}
\hline & HOU & BUS & GOV & ROW & Total \\
\hline 1) Net lending: from the BEA NIPA & 554 & -249 & -782 & 478 & 0 \\
\hline 2) Net Lending: from the Fed FOF & 895 & 115 & -725 & 79 & 365 \\
\hline US official reserves and SDR & & & -6 & 6 & 0 \\
\hline Checkable deposits and currency & 149 & -280 & 101 & 31 & 0 \\
\hline Time and saving deposits & 502 & -493 & 14 & -23 & 0 \\
\hline Money-market fund shares & -45 & 31 & 12 & 1 & 0 \\
\hline Debt securities & 157 & 69 & -703 & 478 & 0 \\
\hline Loans & -450 & 332 & 119 & 0 & 0 \\
\hline Equities & 36 & 348 & 5 & -389 & 0 \\
\hline Mutual fund shares & 58 & -68 & 3 & 7 & 0 \\
\hline Life insurance reserves & 36 & -37 & & & 0 \\
\hline Pension entitlements & 436 & -436 & & & 0 \\
\hline US direct investment abroad & & 323 & & -323 & 0 \\
\hline Foreign direct investment in the US & & -353 & & 353 & 0 \\
\hline Other assets & 17 & 679 & -269 & -63 & 365 \\
\hline 3) Discrepancy (1-2) & -341 & -364 & -58 & 399 & -365 \\
\hline
\end{tabular}

Source: BEA, Federal Reserve and author's definitions. HOU represents households and non-profit institutions, BUS business, GOV government and ROW the rest of the world. 
Figure 1

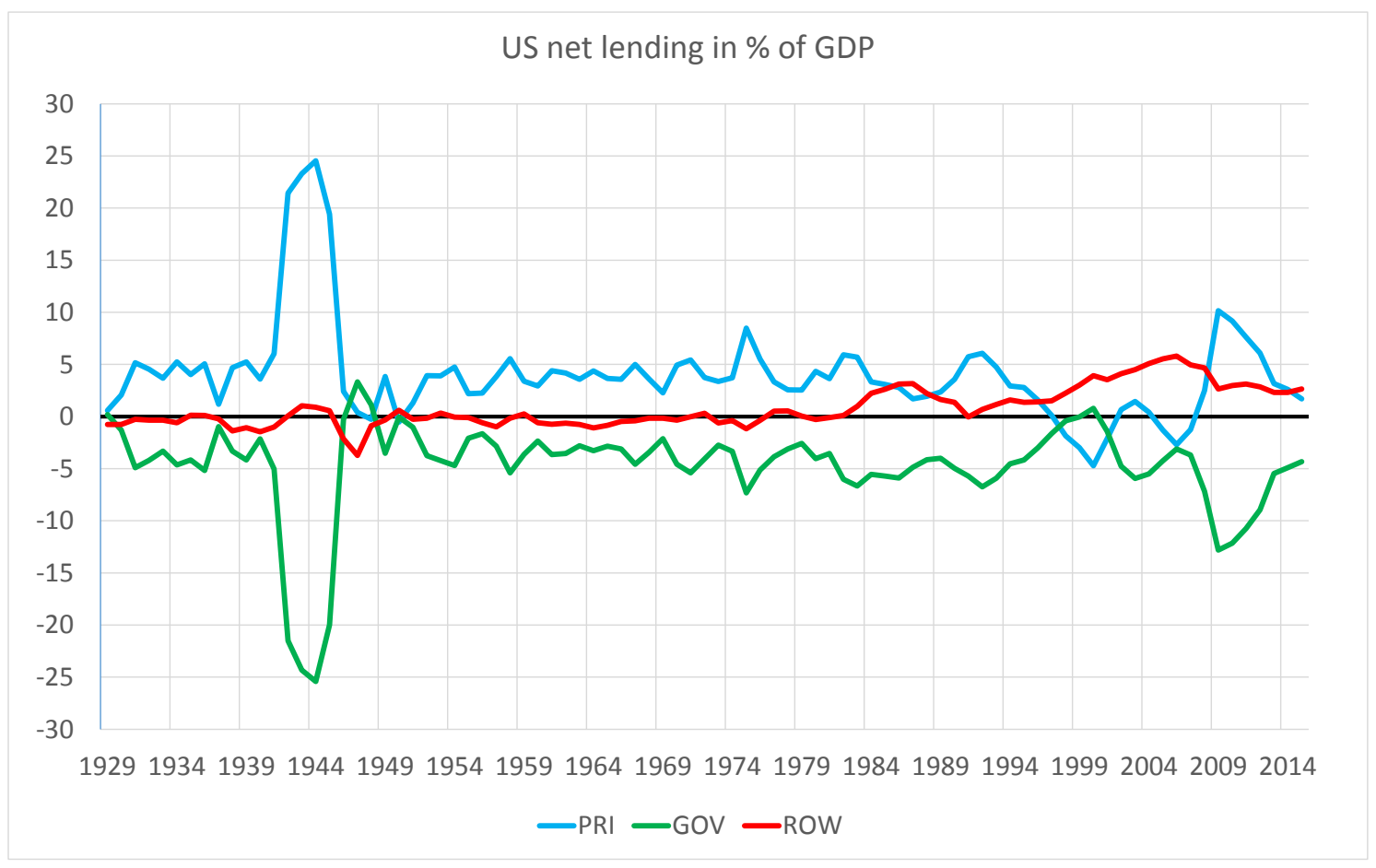

Figure 2

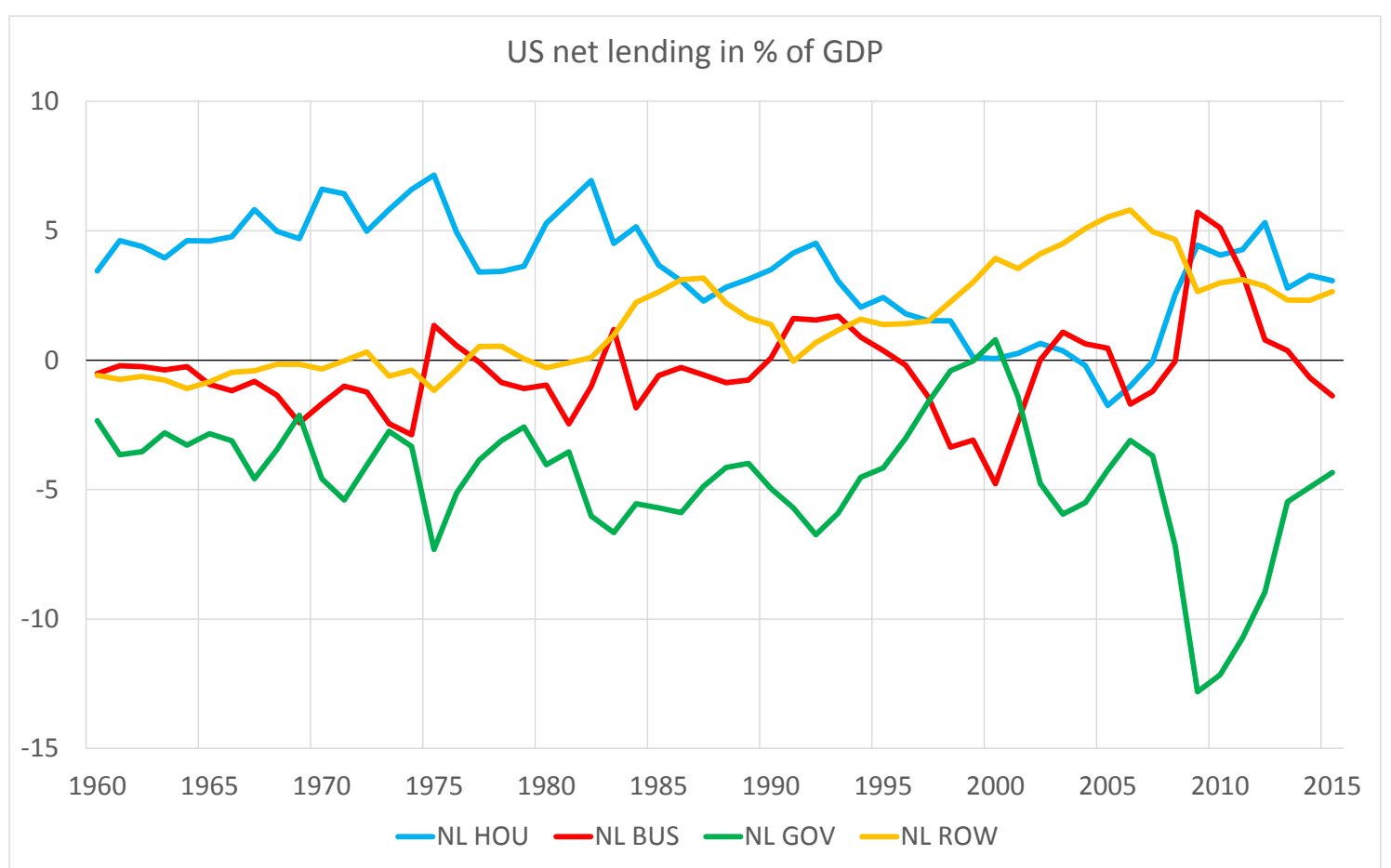


Figure 3

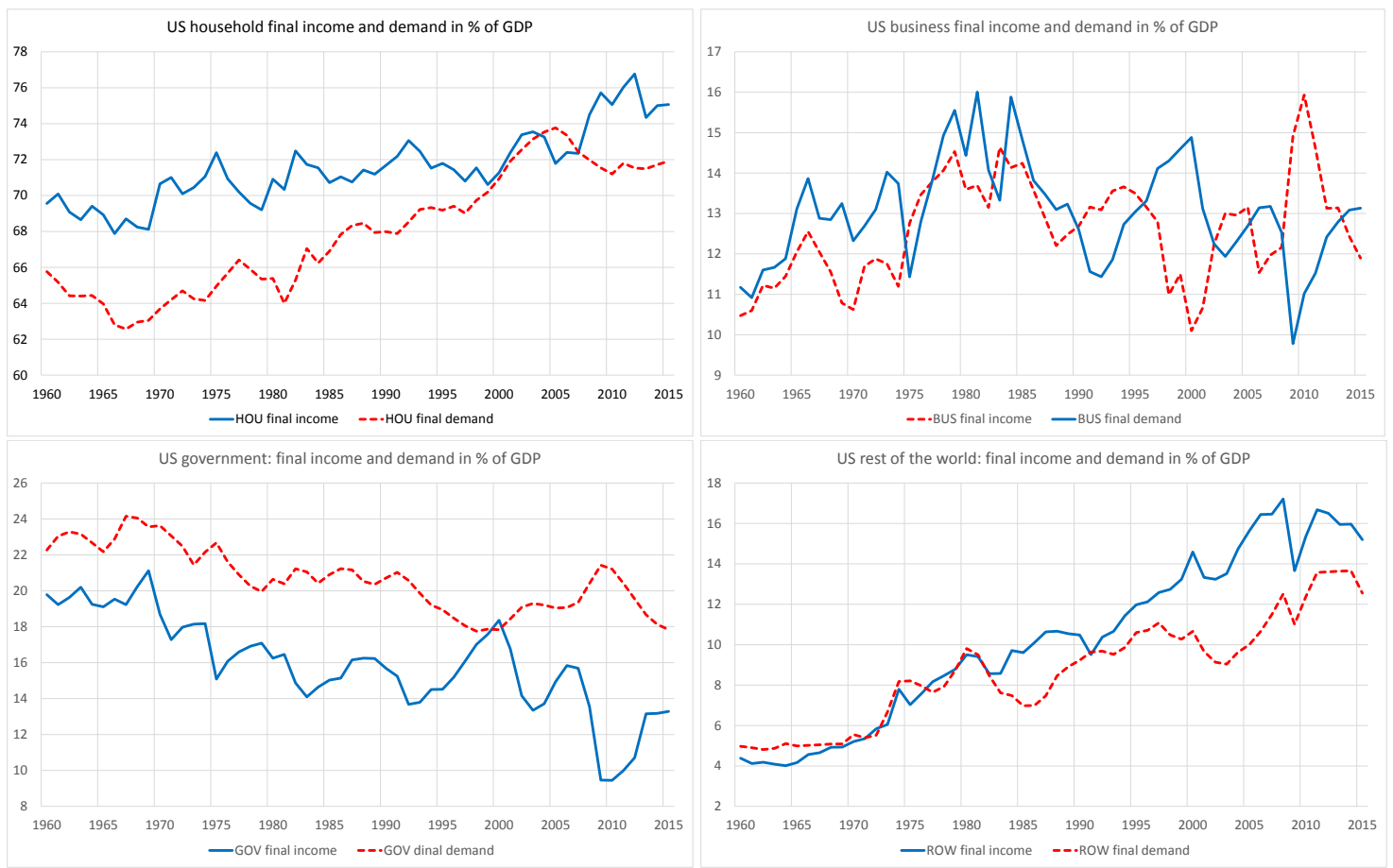

Figure 4

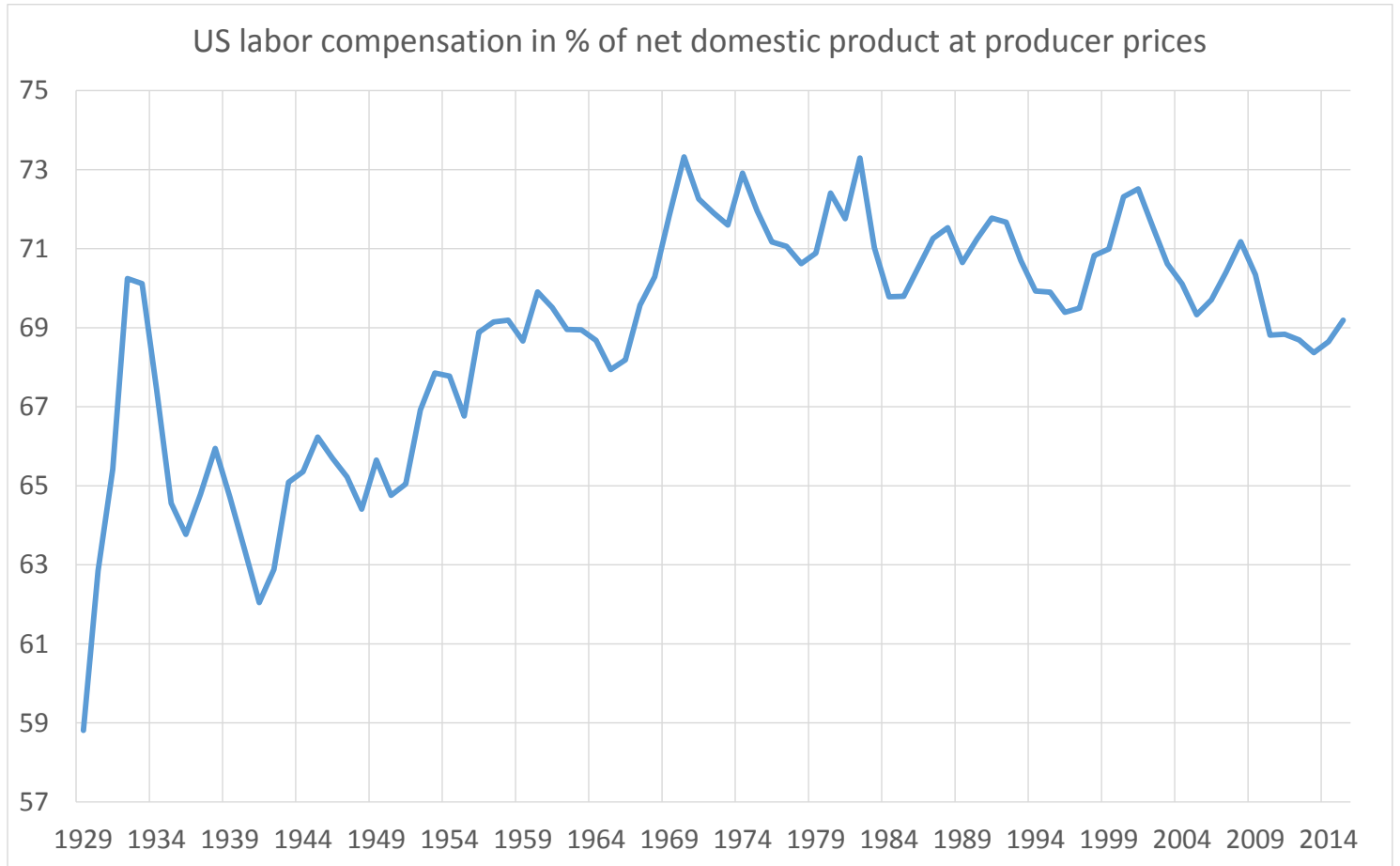


Figure 5

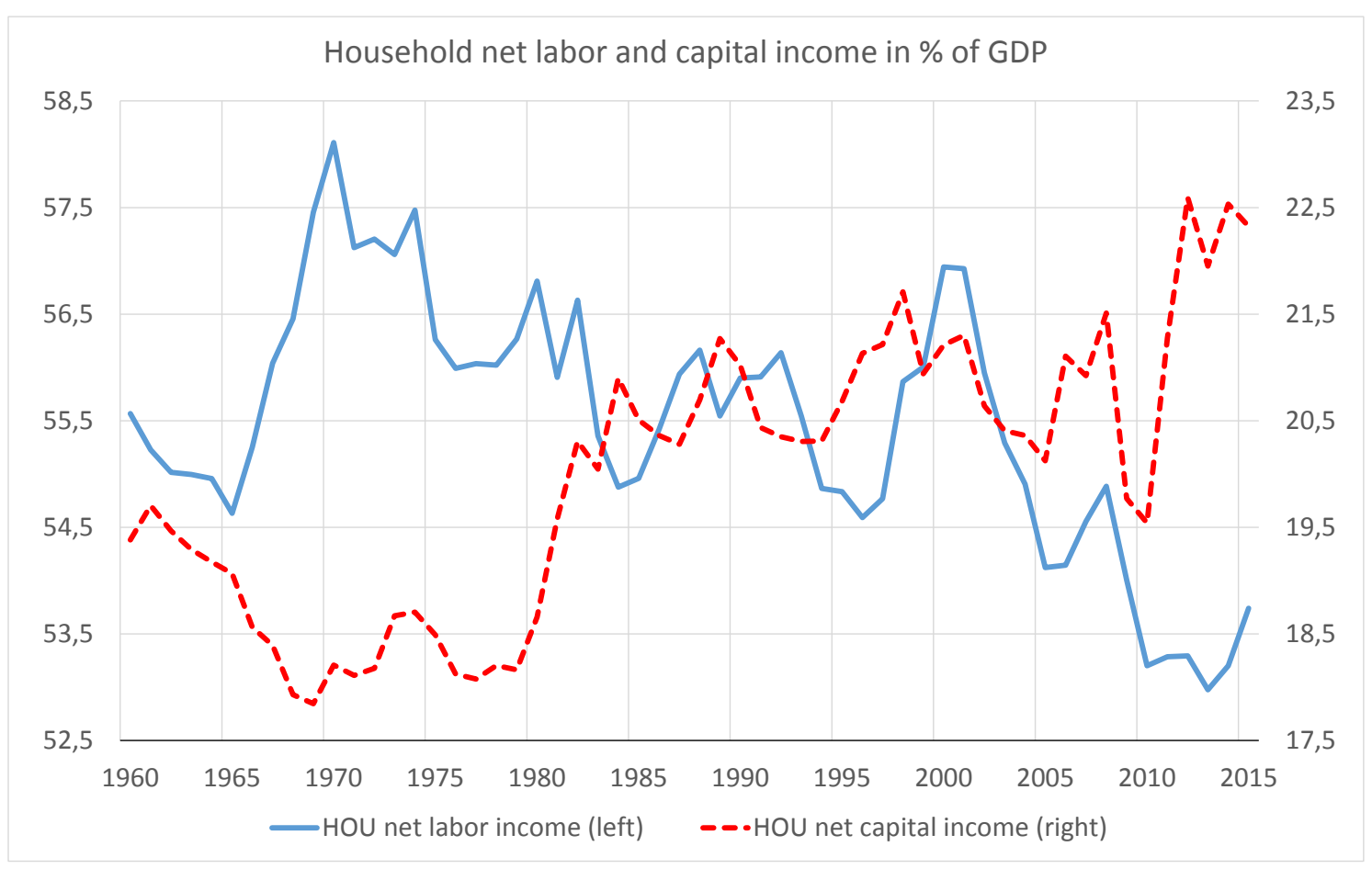

Figure 6

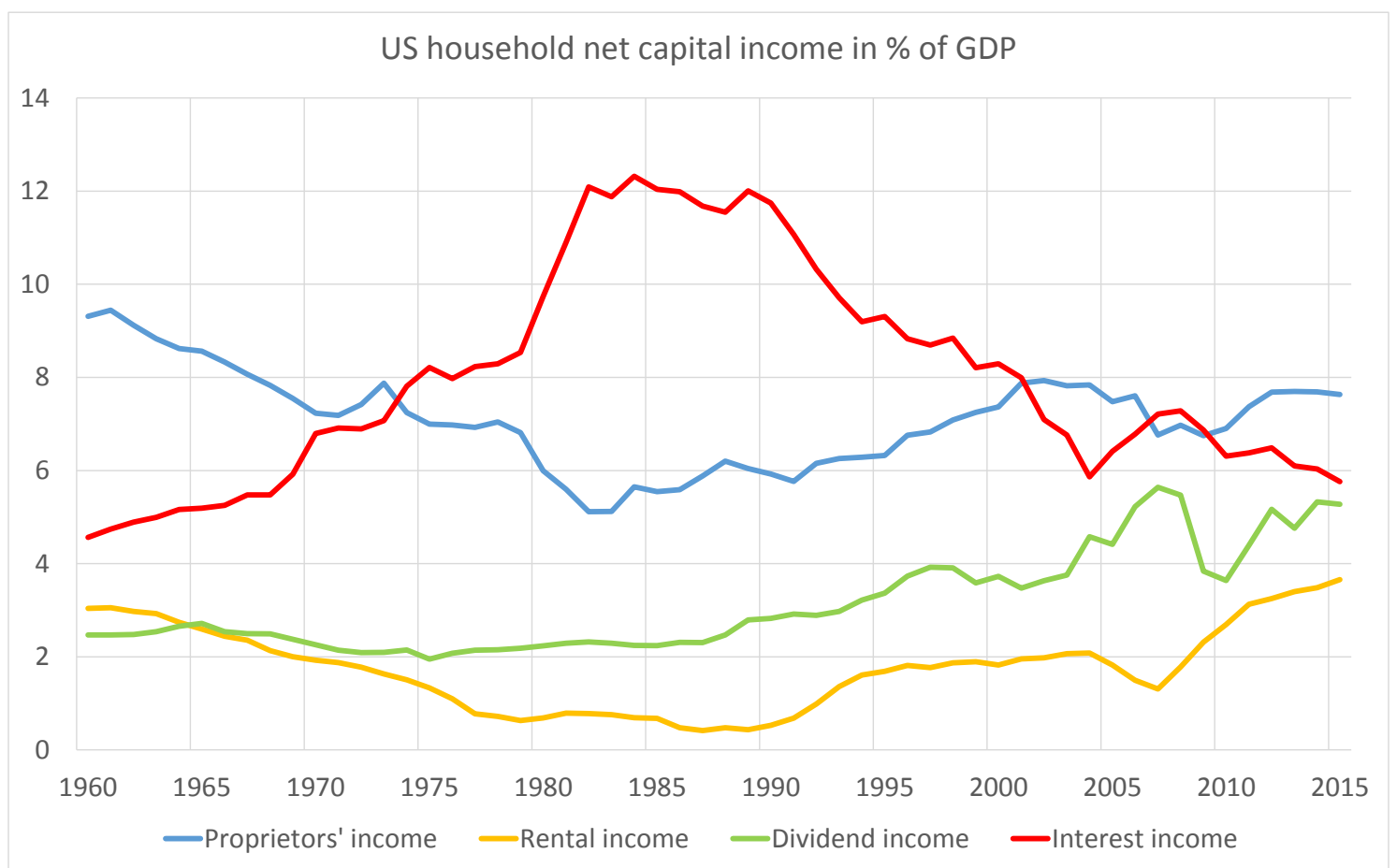


Figure 7

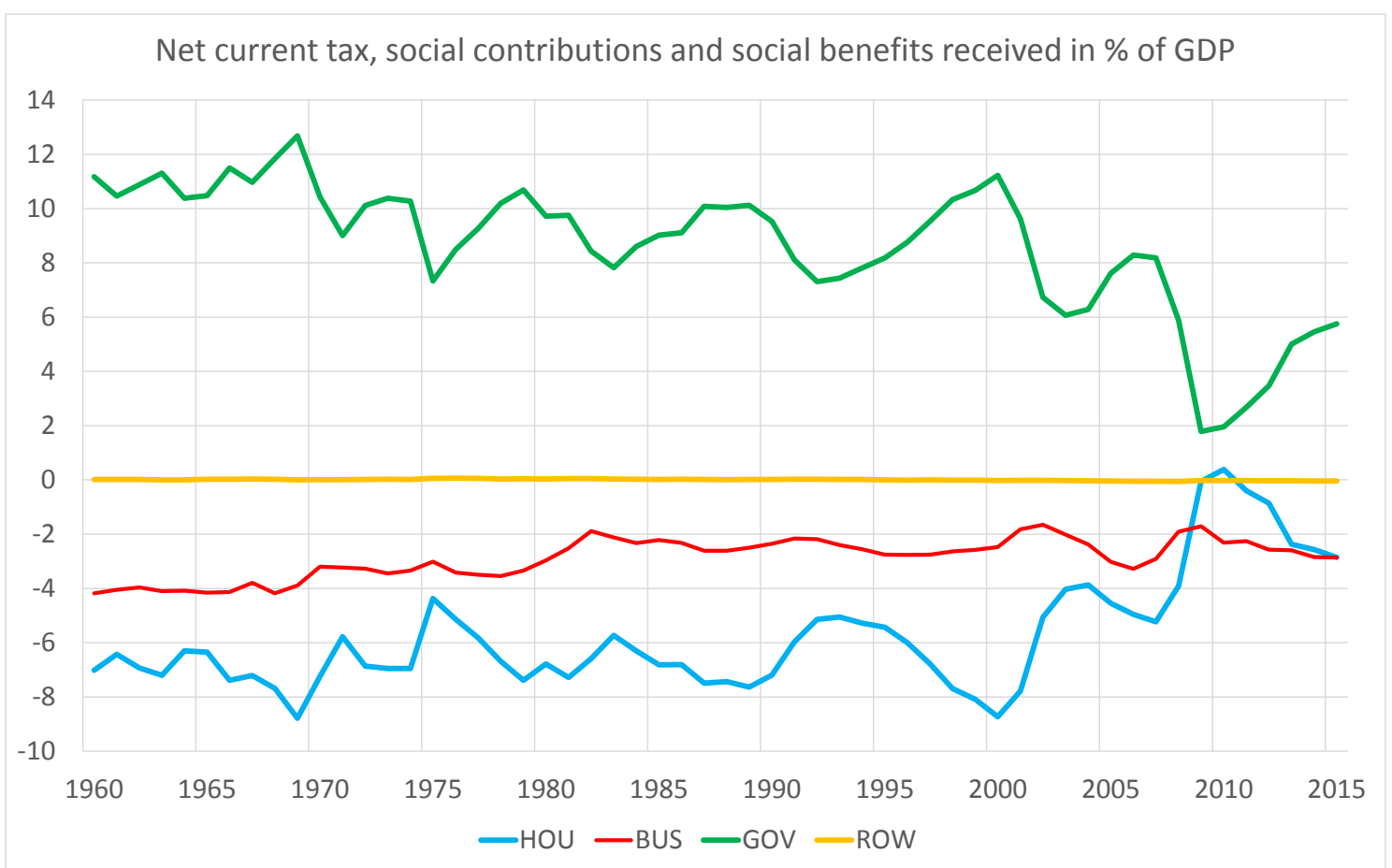

